Siedlecki Zygmunt, Shaik Fasi A., Nowak Karol, Grzyb Sebastian, Śniegocki Maciej. Historical overview of cranial bone implants: own material or artificial prostheses - short review. Journal of Education, Health and Sport. 2021;11(02):36-40. eISSN 2391-8306. DOI http://dx.doi.org/10.12775/JEHS.2021.11.02.004

https://apcz.umk.pl/czasopisma/index.php/JEHS/article/view/JEHS.2021.11.02.004

https://zenodo.org/record/4529046

The journal has had 5 points in Ministry of Science and Higher Education parametric evaluation. § 8. 2) and § 12. 1. 2) 22.02.2019.

(c) The Authors 2021;

This article is published with open access at Licensee Open Journal Systems of Nicolaus Copernicus University in Torun, Poland

Open Access. This article is distributed under the terms of the Creative Commons Attribution Noncommercial License which permits any noncommercial use, distribution, and reproduction in any medium, provided the original author $(\mathrm{s})$ and source are credited. This is an open access article licensed under the terms of the Creative Commons Attribution Non commercial license Share alike. The authors declare that there is no conflict of interests regarding the publication of this paper.

Received: 28.01.2021. Revised: 05.02.2021. Accepted: 10.02.2021.

\title{
Historical overview of cranial bone implants: own material or artificial prostheses - short review
}

\author{
Zygmunt Siedlecki ${ }^{1}$, Fasi A. Shaik ${ }^{2}$, Karol Nowak ${ }^{1}$, Sebastian Grzyb ${ }^{3}$, Maciej Śniegocki ${ }^{1}$
}

1. Department of Neurosurgery, Neurotraumatology and Pediatric Neurosurgery, The Ludwik Rydygier Collegium Medicum in Bydgoszcz, The Nicolaus Copernicus University in Torun

2. Department of Biotechnology, University of Wolverhampton, United Kingdom. Present: Jain University, India

3. Department of Clinical Pharmacology, The Ludwik Rydygier Collegium Medicum in Bydgoszcz, The Nicolaus Copernicus University in Torun

Corresponding address:

Dr. med. Zygmunt Siedlecki Department of Neurosurgery, Neurotraumatology and Pediatric Neurosurgery, the Ludwik Rydygier Collegium Medicum in Bydgoszcz,

ul. Skłodowskiej-Curie 9

85-094 Bydgoszcz

tel.: +48606302680

e-mail: siedlecki@cm.umk.pl 


\begin{abstract}
We present a brief report on the different types of skull bone prostheses used in cranioplasty. Skull defects, most often resulting from severe head injuries, have been known since the times of Ancient Egypt. Ethnographic reports indicate that at that time the skull defects were restored with golden plates. In the following centuries of medical development, especially in modern centuries, cranioplasty has been performed more widely. Cranioplasty began to be performed also in defects after craniectomy. Such craniectomies have been performed for treatment brain hemorrhages, strokes, tumors with severe edema. A common dilemma is whether artificial prostheses are better or own bone material. We present a brief historical overview and the actual state based on the procedures performed in our neurosurgical department in Collegium Medicum in Bydgoszcz.
\end{abstract}

Key words: cranioplasty, bone defect, implants, history

\title{
Introduction
}

Skull defects have been a medical problem accompanying human civilization for centuries. Since the formation of Homo sapiens, that is 260-350 thousand years ago, skull and brain injuries have been observed [1]. Fractures of the skull occurred during hunting and tribal fights. Old excavations from the Palaeolithic period, i.e. the split stone period, indicate defects of the skull bones, also related to head injuries caused by such stone hardware [1].

Archaeological reports from Ancient Egypt indicate that cranial defects were restored with golden plates [1,2]. It can therefore be concluded, from the historical point of view, that the first cranioplasty in the history of medicine took place in Ancient Egypt, and the first material of the skull prosthesis was gold [2].

Daland et al. (1935) reported also cranial fractures and trephining by the Incas of Peru [3]. Daland emphasized that, after such procedures, cranial defects were restored with golden or silver plates, but he questioned the utility of such material [3]. Other materials, such as coca, yerba mate, gourd, shells, coconut, calabash, and plants, were implanted, but all proved to be ineffective as well [3].

In the Middle Ages, as in other fields of medicine, there was a regression and there are no reports in the literature on possible cranioplasty procedures in those times [1,4].

Another literature reports about skull defects repair after injuries were observed in the 16th and 17th centuries. There were reports of such treatments both in Europe and in Persia [4,5]. Persian physician Baha al-Dowleh Razi has published monography entitled Khulasat alTajarib (eng. Summary) [5]. In his work he describes a surgeon who performed procedures consisting in cutting out injured bones of the skull, then cutting, dissecting and preparing a dog's skull of the same shape and placing it on the damaged part of patient's skull [5]. This surgeon never was not definitively identified [5]. Nevertheless, this report is important due to the use of xenograft bone in cranioplasty for the first time in the history of medicine. In Europe, during the 16th - 17th centuries, literature reports the use of golden or silver plates $[3,6]$. The first similar report to this written by Baha al-Dowleh Razi, about successful cranioplasty of animal bone graft was published in 1668 by the Dutch surgeon Job Janszoon van Meekeren [6]. 
This report described a sword-wounded Russian nobleman with cranial defect. The injury was repaired with a dog skull graft [6]. As a theological curiosity from that time, it should be mentioned that the patient was allegedly threatened with excommunication from the church because of animal tissue implanted in the man's head [6].

In the following centuries, until the present day, more and more artificial materials for cranioplasty appeared. At the same time, the human bone was used as an autogenous material [7]. The discussion on whether the optimal course is artificial material or whether the natural bone is being lifted for today is written about this later in this article.

\section{Review of materials for cranioplasty}

The materials used for cranioplasty are divided into bone and artificial materials. Bone is currently most often the bone, which has been stored since the craniectomy procedure, then the same bone flap restored to the defect site. Such bone can be secured in a pocket in the subcutaneous tissue or stored in a special tissue bank [7].

Animal bones and other bones (other than one's own) are of historical importance nowadays [6], and at the time when the development of biotechnology developed such good prostheses, such a solution is rather not used.

Artificial materials can be divided into metal and non-metal [8]. The disadvantage of metal implants is their thermal conductivity. The use of metal materials is not observed in many neurosurgical centers. They are of rather historical importance [6]. The reason for this is, as described above, the advancement of biotechnology that has developed such good meterials that are firm and durable. They protect the brain like a metal plate and do not have the disadvantage of metal such as thermal conductivity [8]. The exception are titanium prostheses, which, according to some authors, are still used as a secondary repair mechanism after a primary repair has failed [8].

Historical materials for cranioplasty, including those that have been used in history and are no longer used, are shown in Table 1 [8].

Table 1. Bone protheses materials used from past till now [8]

\begin{tabular}{|c|c|c|c|}
\hline \multicolumn{2}{|l|}{ bone material } & \multicolumn{2}{|l|}{ artificial prosthesis } \\
\hline \multirow[t]{6}{*}{ own bone plate } & \multirow[t]{6}{*}{ aninal bone } & metal bone substitutes & non-metal bone substitutes \\
\hline & & Gold and Silver & Celluloid \\
\hline & & Platinum, Lead, Aluminum & Acrylics \\
\hline & & Alloys & PEEK \\
\hline & & Titanium & Ceramics \\
\hline & & Tantalum & Resorbable Implants \\
\hline
\end{tabular}




\section{The facts in our neurosurgical department}

In the years 2010-2020, the our neurosurgical department 98 cranioplasty procedures were performed. 94 of all procedures (95.92\%) consisted in supplementing the skull bone defect with Cobudix ${ }^{\circledR}$ material, which is a bone prosthesis used in our department. Of the operated patients using Cobudix ${ }^{\circledR}$ prothesis , $85.11 \%$ were people after severe brain injury (most often car accidents, then falls from heights), 9.57\% were people after surgery for a ruptured brain aneurysm, while $5.32 \%$ were people after decompression craniectomy in severe ischemic stroke.

Four patients were operated on with different techniques. In two patients, bones were stored into the abdominal wall fat tissue. One was patient with severe brain injury, operated urgently due to acute subdural hematoma. Due to severe brain edema, the bone flap was removed and placed in a pocket made in the abdominal subcutaneous tissue. Cranioplasty took place after 8 weeks. The attention of neurosurgeons was drawn to the tendency towards osteolysis of the bone flap, but the procedure was correct and the outcome was favorable.

The second patient had decompression due to severe edema and ischemic brain stroke. The cranioplasty was performed correctly, the operators' conclusions were consistent with the previous case.

The patient's own bone is a very good material for filling a craniectomy defect [9], however, cranioplasty should not be performed too far in time, because bone flap can be deformed by osteolysis in the adipose tissue and may not fit the cranial defect correctly.

Legal aspects related to consent to the procedure may also play an important role. Brain decompression operations, which save the patient's life and remove the bone flap, are performed on the basis of implicit consent [10]. Such a sick person, in a serious condition, cannot consent to the procedure and he is undergoing emergency surgery. Some lawyers have doubts as to whether the surgical procedure can be extended to include securing the bone flap in the abdominal wall. It is associated with surgical manipulations that go beyond saving lives. Other prostheses used in our neurosurgical center are polymethylacrylic mass made in a form adapted to the shape of the defect. Outcome was good.

Another prosthesis in a patient with a large defect in the frontal bone was made of a specially processed hydoxyapatite by the manufacturer. Outcome was good.

It should be emphasized that now, at the beginning of the third decade of the twenty-first century and in the second decade of the twenty-first century, the vast majority of skull bone prostheses were made on an individual order, for a specific patient [11]. Such individual prostheses are produced on the basis of 3D computed tomography and are optimally adapted to the shape of the bone defect [11]. 


\section{Conclusions}

1. Currently, mainly due to thermal conductivity, cranioplasty is generally not performed with metal materials, however titanium is used as a secondary repair mechanism after a primary repair has failed.

2. The biotechnology development allowed to perform such good cranial prostheses, that there are no evident benefits between them and own bone. The decision on which material to use in cranioplasty depends on the preferences of the neurosurgeon and the individual case of each patients

Competing Interests: The authors declare that they have no conflict of interest.

Authors' contributions: ZS performed numerous of cranioplasty procedures using both articifial materials and own bone flaps, therefore he came up with the idea of describing this review. KN and SG reviewed the literature. FA - master of science in Biotechnology, University of Wolverhampton, UK, who, as a biotechnologist, assessed materials in cranioplasty procedures and made a valuable contribution to this manuscript. MŚ checked the written manuscript in formal terms.

\section{References}

1. CB, C. (1959). Cranioplasty in prehistoric times. Bulletin of the Los Angeles Neurological Society, 24(1), 18.

2. Durand, J. L., Renier, D., \& Marchac, D. (1997, February). The history of cranioplasty. In Annales de chirurgie plastique et esthetique (Vol. 42, No. 1, pp. 75-83).

3. Daland, J. (1935). Depressed fracture and trephining of the skull by the Incas of Peru. Ann Med Hist, 7, 550558.

4. Abhay, S., \& Haines, S. J. (1997). Repairing holes in the head: a history of cranioplasty. Neurosurgery, 40(3), 588-603.

5. Shoja, M. M., Agutter, P. S., Loukas, M., Shokouhi, G., Khalili, M., Farhoudi, M., \& Tubbs, R. S. (2012). Cranioplasty in medieval Persia and the potential spread of this knowledge to Europe. Child's Nervous System, 28(12), 1993-1996.

6. Bonfield, C. M., Kumar, A. R., \& Gerszten, P. C. (2014). The history of military cranioplasty. Neurosurgical focus, 36(4), E18.

7. Mitchell, A. B. (1917). Repair of injuries to the skull by perforated plates. British Journal of Surgery, 5(17), 40-41.

8. Harris, D. A., Fong, A. J., Buchanan, E. P., Monson, L., Khechoyan, D., \& Lam, S. (2014). History of synthetic materials in alloplastic cranioplasty. Neurosurgical focus, 36(4), E20.

9. Tybor, K., Fortuniak, J., Komuński, P., Papierz, T., Andrzejak, S., Jaskólski, D., ... \& Zawirski, M. (2005). Uzupełnianie ubytków koœci pokrywy czaszki autologicznym płatem kostnym przechowywanym w powłokach brzucha. Neurologia i Neurochirurgia Polska, 39(3), 220-224.

10. Siedlecki, Z., Gutkowska, A., Nowak, K., \& Śniegocki, M. (2021). Cranioplasty as neurosurgical procedure with potential risk of legal claims. Journal of Education, Health and Sport, 11(1), 170-176.

11. Markowska, O., Gardzińska, A., Chrzan, R., Urbanik, A., \& Miechowicz, S. (2009). Use of computer tomography and 3DP Rapid Prototyping technique in cranioplasty planning: analysis of accuracy of bone defect modelling. Polish Journal of Radiology, 74(4). 